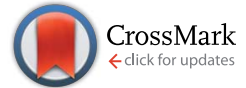

Cite this: RSC Adv., 2017, 7, 389

Received 6th October 2016

Accepted 25th October 2016

DOI: $10.1039 / c 6 r a 24799 g$

www.rsc.org/advances

\section{Packing-induced solid-state fluorescence and thermochromic behavior of peptidic luminophores $\uparrow$}

\begin{abstract}
Apurba Pramanik and Debasish Haldar*
The effect of packing on the solid state fluorescent propensities of peptidic luminophores has been investigated. A series of peptides containing 6 -nitro-coumarin-3-carboxylic acid and $\alpha$-aminoisobutyric acid (Aib) has been synthesized to study the structure-property relationship and stimuli responsive emission properties of the luminophores. In spite of the presence of a coumarin chromophore, peptide 2 exhibits no solid state fluorescence. The alkyl chains of Aib affect the solid state molecular packing modes and optoelectronic properties significantly. However, the fluorescence microscopy confirmed the change of blue fluorescence of peptide 3 in crystal and in amorphous states. The X-ray crystallography sheds some light on the molecular orientation, packing and the diverse degree of $\pi-\pi$ stacking orbital overlap of adjacent coumarin chromophores of the peptide 3. Irrespective of coumarin chromophore, the peptides exhibit different packing-induced solid state emission properties varying from one peptide to another, which highlights the effect of Aib side chains.
\end{abstract}

\section{Introduction}

Molecular packing directed luminescence is highly important in crystal engineering, where a solid material exhibits change in photoluminescence colour in response to external stimuli. ${ }^{1}$ In a recent review, Yang et al. summarized the effect of alkyl length on the solid-state fluorescence and mechanochromic behaviour of organic days. ${ }^{2}$ The organic materials with packing directed luminescence are of great interest due to practical applications such as lasers, OLEDs, optical data storage, ${ }^{3}$ two-photon photoluminescence (PL) microscopy, ${ }^{4}$ optical switching ${ }^{5}$ and limiting. ${ }^{6}$ Various external stimuli and strategies such as chemical modification, ${ }^{7-10}$ mechanical control of the packing modes, ${ }^{11-16}$ co-crystals, ${ }^{17,18}$ have been used to alter the fluorescence properties. Several reports have shown the influences of packing on the fluorescent colors of various synthetic organic dyes. ${ }^{19,20}$ For example, Mei and co-workers have shown the mechanochromism triggered fluorescent colour switching among polymorphs of emodin. ${ }^{21}$ Wang et al. explained the polymorphism and pseudo-polymorphism directed fluorescence switching of $N, N$-di( $n$-butyl)-quinacridone. ${ }^{22}$ Hariharan et al. have engineered the solid state packing and colour of

Department of Chemical Sciences, Indian Institute of Science Education and Research Kolkata, Mohanpur, West Bengal 741246, India. E-mail: deba_h76@yahoo.com; deba_h76@iiserkol.ac.in; Fax: +91 3325873020; Tel: +91 3325873119

$\dagger$ Electronic supplementary information (ESI) available: Synthesis and characterization of trisamides, ${ }^{1} \mathrm{H}$ NMR, ${ }^{13} \mathrm{C}$ NMR, Fig. ESI S1-S8, Fig. S1-S12. CCDC 1505407, 1505411 and 1505412. For ESI and crystallographic data in CIF or other electronic format see DOI: 10.1039/c6ra24799g pyrene by acetylation. ${ }^{23}$ Fraser and co-workers have reported the polymorphism induced reversible mechanochromic luminescence for difluoroboronavobenzone. ${ }^{24}$ But, controlling molecular orientation and diverse degree of orbital overlap of adjacent chromophores is still challenging. ${ }^{25}$ However, the influences of packing on the fluorescent colors of peptides/ foldamers are relatively rare. ${ }^{26}$

Coumarin a natural product has been used as gain medium in blue-green dye lasers and sensitizer for photovoltaic cell. ${ }^{27}$ Coumarin derivative also have been used to develop array for protein sensing. ${ }^{28}$ Ting and co-workers have used coumarin fluorophore ligation for imaging protein-protein interaction inside living cell. ${ }^{29}$ Herein, we have synthesized a series of nitropeptides containing 6-nitro-coumarin-3-carboxylic acid methyl ester, $\alpha$-aminoisobutyric acid (Aib) and investigated their structures and optical properties. Aib is conformationally rigid and helicogenic. So, introduction of Aib will be interesting not only for molecular conformation, but also for controlling molecular orientation (to adjust the steric hindrance) and crystal packing. Interestingly, the 6-nitro-coumarin-3-carboxylic acid methyl ester 1 exhibits red-green birefringence under cross-polarized light, before and after heating. However, the nitropeptide 2 exhibits no birefringence. The nitropeptide 3 exhibits green-gold birefringence which disappeared on heating. The fluorescence microscopy confirmed the change of blue fluorescence of nitropeptide 3 in crystal and in amorphous state. Finally X-ray crystallography sheds some light on the molecular orientation, packing and the diverse degree of $\pi-\pi$ stacking orbital overlap of adjacent coumarin chromophores of the nitropeptide 3. 


\section{Results and discussion}

For nitropeptides 2 and 3 (Fig. 1), the design principle explored was how to use a chromophore containing aromatic amino acid with helicogenic Aib to develop rigid foldamers and use as fluorescence probe. The introduction of Aib-moiety will increase crystallinity. Moreover, to adjust the steric hindrance Aib is suitable for controlling molecular orientation and crystal packing. Nitropeptide 3 contains two coumarin chromophores connected by a peptide bond. The target compound 6-nitrocoumarin-3-carboxylic acid methyl ester 1 (Fig. 1) was synthesized by following a standard coumarin synthesis protocol (reflux salicyldehyde, dimethyl malonate and piperidine at $80{ }^{\circ} \mathrm{C}$ for $10 \mathrm{~h}$ ) followed by nitration using mixed acid. Nitropeptides 2 and $\mathbf{3}$ were synthesized by conventional solutionphase peptide synthesis methodology using DCC as coupling reagent. The synthesized compounds were purified and characterized by ${ }^{1} \mathrm{H}-\mathrm{NMR},{ }^{13} \mathrm{C}-\mathrm{NMR}$, FT-IR and mass spectrometry (MS) analysis.

First we have investigated the assembly of compound $\mathbf{1}$ and nitropeptides $\mathbf{2}$ and $\mathbf{3}$ in solution phase by different spectroscopic techniques. The solution state UV/vis spectra shows that there is no change of coumarin spectral positions (275 and $335 \mathrm{~nm}$ for $\pi$ to $\pi^{*}$ transition) or intensity of compound 1 in chloroform (ESI Fig. $1 \dagger$ ). Also the nitropeptide 2 shows two peaks at 275 and $335 \mathrm{~nm}$ responsible for $\pi$ to $\pi^{*}$ transition (Fig. 2a) The nitropeptide 3 exhibits three peaks at 260, 300 and $335 \mathrm{~nm}$ and intensity of the bands increases with increasing concentration (Fig. 2b). The typical emission band of coumarin in chloroform solution at $400 \mathrm{~nm}$ also increases (ESI Fig. $2 \dagger$ ) with addition of compound 1. However, the concentration dependence studies show that the emission band responsible for coumarin unit at $400 \mathrm{~nm}$ has quenched with increasing concentration of nitropeptide 2 (Fig. 2c). But for the nitropeptide 3, the characteristic emission bands at $450 \mathrm{~nm}$ increases with increasing concentration (Fig. 2d). The results suggest irrespective of coumarin chromophore, the intermolecular interactions play an important part for the luminophore peptides.

Solid state FT-IR spectroscopy is an excellent method to investigate the structure and assembly pattern of the nitropeptides. The FT-IR region $3500-3200 \mathrm{~cm}^{-1}$ is important for the $\mathrm{N}-\mathrm{H}$ stretching vibrations, however the range $1800-1500 \mathrm{~cm}^{-1}$

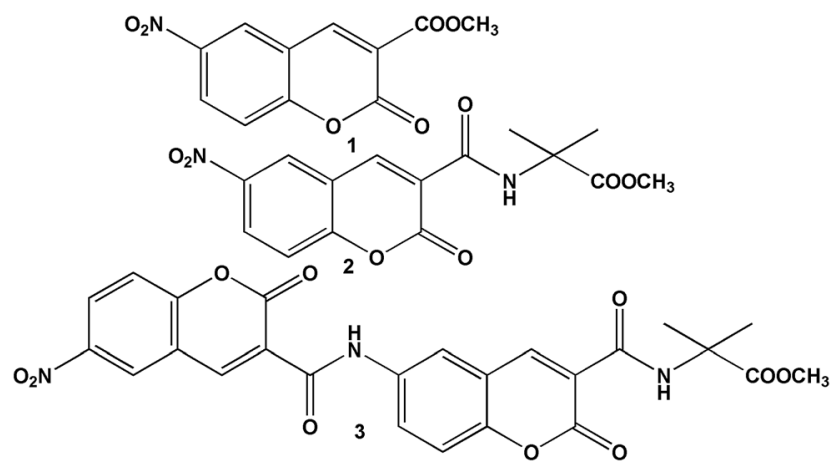

Fig. 1 The schematic presentation of 6-nitro-coumarin-3-carboxylic acid methyl ester 1 and peptides 2 and 3 .
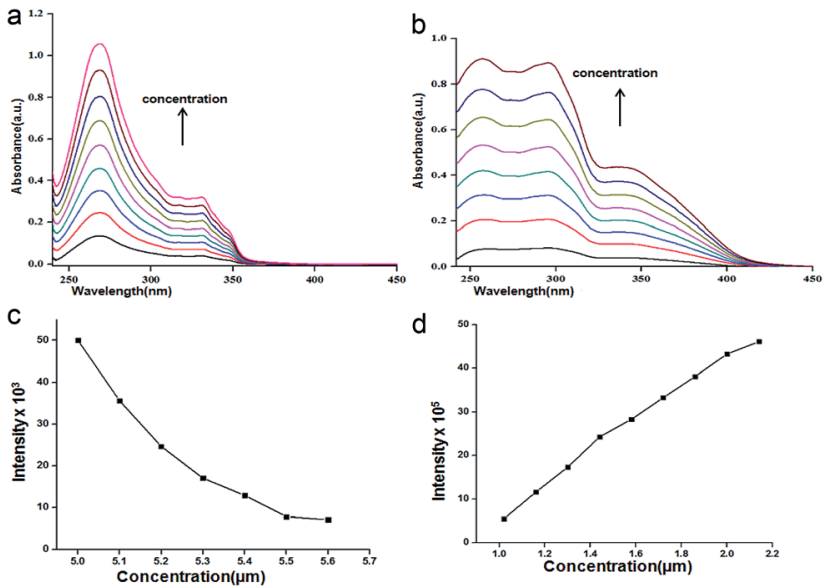

Fig. 2 Concentration dependent UV/Vis spectra of (a) peptide 2 and (b) peptide 3. (c) The plot showing gradual quenching of emission peak at $400 \mathrm{~nm}$ with increasing nitropeptide 2 concentrations ( $\lambda_{\mathrm{ex}}=330$ $\mathrm{nm}$ ). (d) The plot showing gradual increase of emission peak at $450 \mathrm{~nm}$ with increasing nitropeptide 3 concentrations $\left(\lambda_{\mathrm{ex}}=330 \mathrm{~nm}\right)$.

is assigned for the stretching band of amide I and the bending peak of amide II. ${ }^{30}$ The peptides 2 and $\mathbf{3}$ exhibit N-H stretching vibrations at 3351 and $3338 \mathrm{~cm}^{-1}$ and amide I and amide II peaks at 1617,1538 and $1614,1533 \mathrm{~cm}^{-1}$ respectively. ${ }^{30}$ Peaks at 1720 and $1723 \mathrm{~cm}^{-1}$ are responsible for ester functional group (Fig. 3a).

DSC scans were carried out with a second generation highsensitivity METTLER differential scanning calorimeter. For the reproducibility of the results, the experiments were repeated thrice with three different samples. Cooling scans yielded curves are different to the heating scans. This is expected due to change of packing pattern by thermal stimuli. Therefore, only heating scans are discussed in this work. The first DSC heating scan of 6-nitro-coumarin-3-carboxylic acid methyl ester 1 exhibits two peaks at 181.08 and $226.68{ }^{\circ} \mathrm{C}$. The first heating scan DSC experiment (Fig. 3b) clearly shows that the nitropeptide 2 has sharp melting temperature at $149.65^{\circ} \mathrm{C}$. A closure inspection of the first heating scan reveals a weak endothermic transition at $192.58{ }^{\circ} \mathrm{C}$ (Fig. 3b). There is another weak endothermic transition at $218.40{ }^{\circ} \mathrm{C}$. This transition is assigned as melting temperature for nitropeptide $3{ }^{31}$ However, the first DSC cooling scans for nitropeptides 2 and 3 (ESI Fig. $3 \dagger$ ) are void of any crystallization peak which indicates the amorphous nature of melted and cooled samples. ${ }^{31}$

The morphology of the peptides was studied by fieldemission scanning electron microscopic (FE-SEM) measurements. For FE-SEM experiments, dilute solutions $(0.5 \mathrm{mM})$ of above reported peptides in chloroform were placed on a microscopic glass slide and then dried under a vacuum for two days. Fig. 4 depicts the FE-SEM images of the aliphatic-aromatic backbone hybrid peptides. From Fig. 4a the micrographs show the flake like morphology for 6-nitro-coumarin-3-carboxylic acid methyl ester 1 in the self-assembled state. Peptides 2 exhibits microsphere morphology (Fig. 4b) with a diameter ca. $400 \mathrm{~nm}$. Peptide 3 exhibits fused microsphere like morphology (Fig. 4, panel $\mathrm{c}$ and $\mathrm{d}$ respectively). 

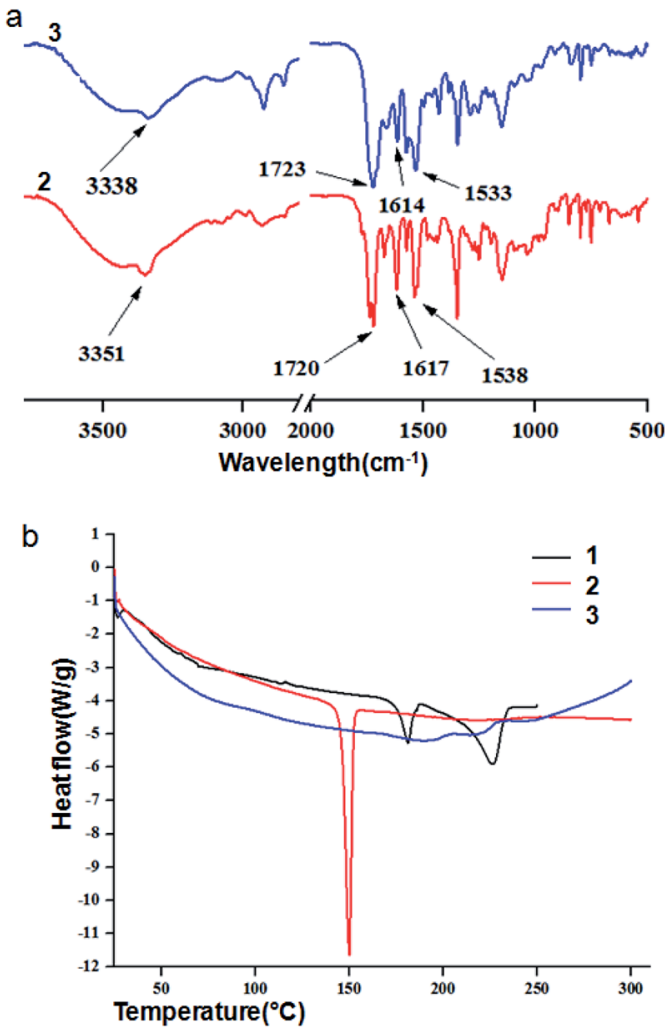

Fig. 3 (a) The solid state FT-IR spectra of nitropeptides 2 (red) and 3 (blue). (b) The DSC stack plot of (black) 6-nitro-coumarin-3-carboxylic acid methyl ester 1, (red) nitropeptide 2 and (blue) nitropeptide 3.

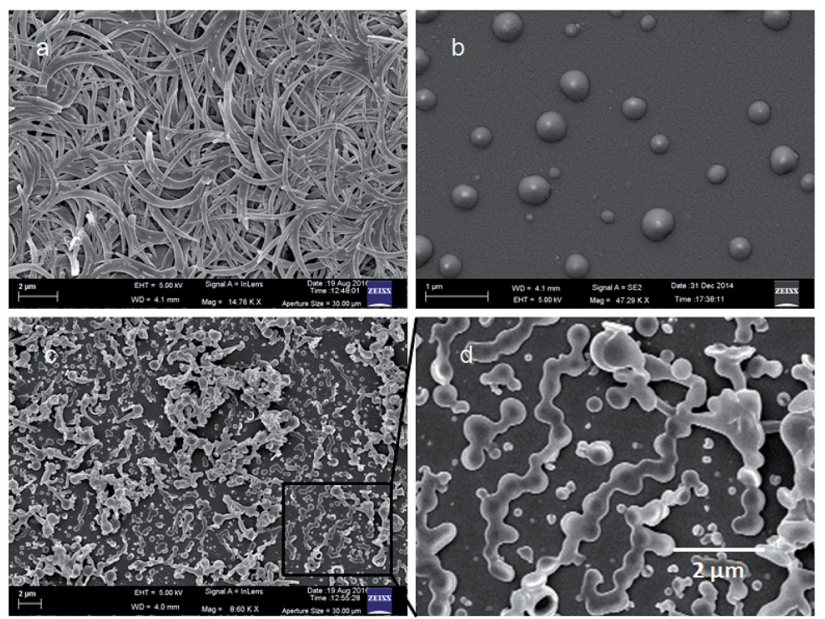

Fig. 4 The FE-SEM images (a) flake like morphology of compound 1 , (b) microsphere morphology of peptide 2 and (c) and (d) fused microsphere like morphology of peptide 3 .

The thermal effect and change of optical properties of the nitropeptides were studied by polarized optical microscopy (POM). The 6-nitro-coumarin-3-carboxylic acid methyl ester 1 crystals exhibit red-green birefringence under polarized light (Fig. 5a and d). The crystals of nitropeptide 2 do not show any birefringence by POM (Fig. $5 \mathrm{~b}$ and e). However, the nitropeptide 3 exhibits green-gold birefringence under polarized light (Fig. 5c and f). Fig. $5 \mathrm{~g}$ and $\mathrm{j}$ show images of samples of $\mathbf{1}$ that were cooled from the melt. The Fig. $5 \mathrm{j}$ shows clearly that the 6-nitrocoumarin-3-carboxylic acid methyl ester from crystal from melt and the red-green birefringence under polarized light has persisted. The samples of nitropeptide 2 that were cooled from the melt show amorphous nature and do not show any birefringence by POM (Fig. $5 \mathrm{~h}$ and k). The same effect was observed when nitropeptide 3 was cooled from the melt. This indicates that the stability of the amorphous state under ambient conditions is high and the amorphous compound does not exhibit birefringence under polarized light (Fig. $5 \mathrm{i}$ and $\mathrm{l}$ ).

To explore the relationship between the emission of the crystals and their amorphous state, fluorescence microscopy were performed. ${ }^{32,33}$ The 6-nitro-coumarin-3-carboxylic acid methyl ester 1 crystals show blue emission on excitation at $330 \mathrm{~nm}$ (Fig. 6a and d). Irrespective of presence of 6-nitrocoumarin-3-carboxylic acid chromophore, the crystals of nitropeptide 2 do not show any emission on excitation at $330 \mathrm{~nm}$ (Fig. 6b and e). However, the nitropeptide 3 containing two coumarin chromophores connected by a peptide bond exhibits blue emission on excitation at $330 \mathrm{~nm}$ (Fig. $6 \mathrm{c}$ and f). The Fig. $6 \mathrm{j}$ clearly shows that the crystal of 6-nitro-coumarin-3-carboxylic acid methyl ester 1 obtained from melt shows blue emission. But the samples of nitropeptide 2 (Fig. $6 \mathrm{~h}$ and k) and 3 (Fig. $6 \mathrm{i}$ and 1) that were cooled from the melt do not show blue emission on excitation at $330 \mathrm{~nm}$. Sample decomposition is not an issue and confirmed by NMR, FT-IR and UV/Vis spectroscopy. This indicates that irrespective of the presence of coumarin
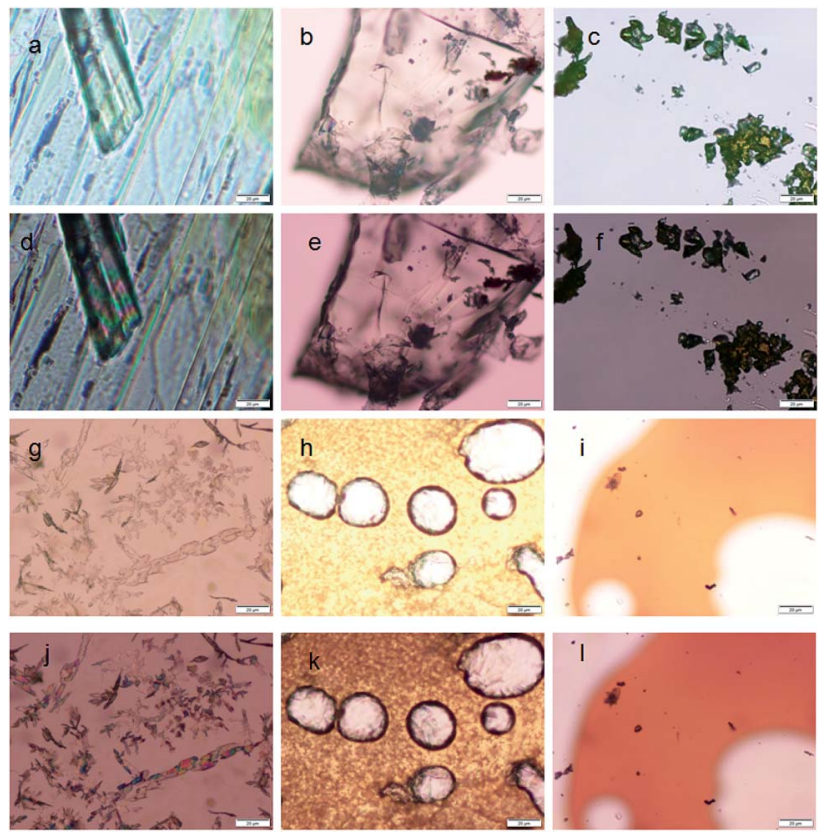

Fig. 5 The optical microscopic images of (a) compound 1, (b) nitropeptide 2 and (c) nitropeptide 3. (d) Compound 1, (e) nitropeptide 2 and (f) nitropeptide 3 under polarized light. The optical microscopic images of solid obtained by cooling of melt of $(\mathrm{g})$ compound 1, (h) nitropeptide 2 and (i) nitropeptide 3 . The solid obtained by cooling of melt of (j) compound 1, (k) nitropeptide 2 and (l) nitropeptide 3 respectively under polarized light. 

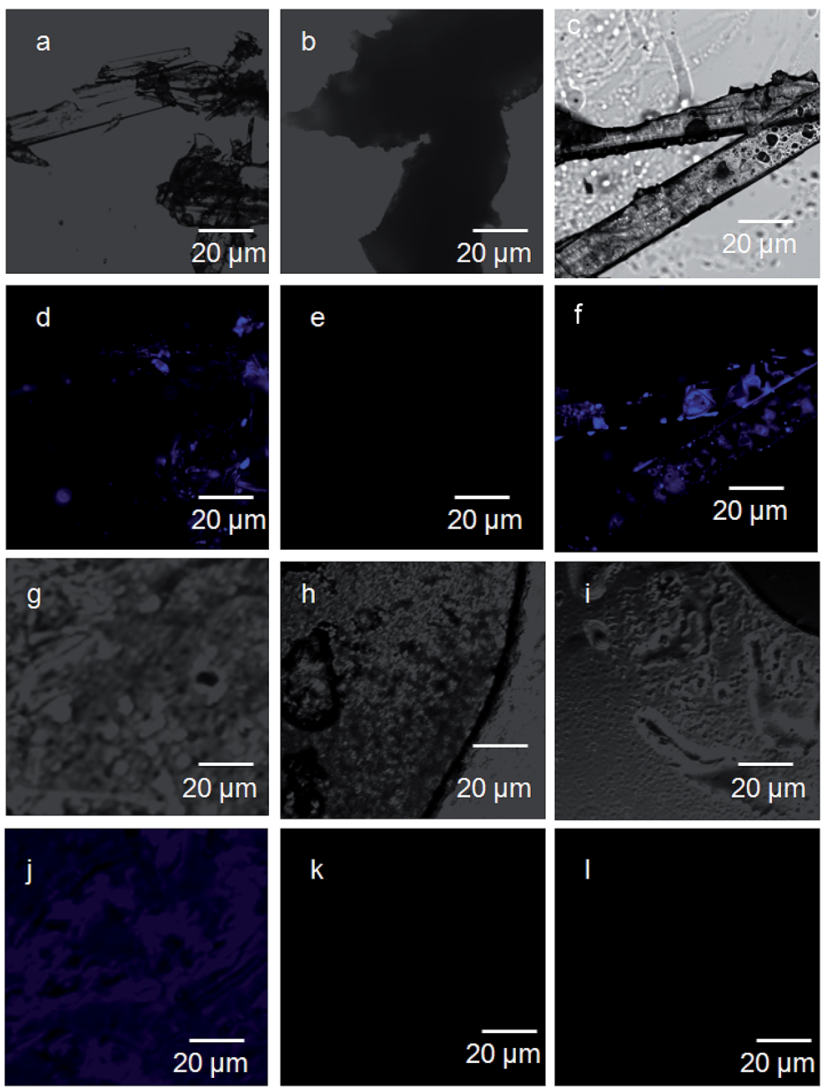

Fig. 6 The fluorescence microscopic images of (a) compound 1, (b) nitropeptide 2 and (c) nitropeptide 3. (d) Compound 1, (e) nitropeptide 2 and (f) nitropeptide 3 on excitation at $330 \mathrm{~nm}$. The fluorescence microscopic images of solid obtained by cooling of melt of $(\mathrm{g})$ compound 1, (h) nitropeptide 2 and (i) nitropeptide 3 . The solid obtained by cooling of melt of (j) compound 1, (k) nitropeptide 2 and (l) nitropeptide 3 on excitation at $330 \mathrm{~nm}$.

chromophore, the fluorescence properties of the nitro peptides depend on the packing of the molecules in crystal and amorphous state.

To explore the relationship between the emission of the solid systems and crystal structure, single crystal X-ray diffraction analysis were performed. The monoclinic light yellow crystals of 6nitro-coumarin-3-carboxylic acid methyl ester 1 were obtained from methanol solution by slow evaporation (ESI Fig. $4 \dagger$ ). There is only one molecule in the asymmetric unit (ESI Fig. $5 \dagger) .{ }^{34}$ In higher order packing the molecules are in anti parallel arrangements and stabilized by multiple face to face, face to edge and edge to edge $\pi-\pi$ stacking interactions (Fig. 7a). We observed a $\pi-\pi$ stacking distance of $3.25 \AA$. The closest $\mathrm{C}-\mathrm{C}$ distance between two coumarin units is $3.78 \AA$. But the centroid to centroid distance is $5.08 \AA$. Hence, the week $\pi-\pi$ interactions between the coumarin units are responsible for the blue emission in solid state. Wang et al. have reported that the crystal phases with stronger $\pi-\pi$ interactions will exhibit maximum emission at a longer wavelength region, however the crystal phases with relatively weaker $\pi-\pi$ interactions will show emission at a shorter wavelength region. ${ }^{22}$ The triclinic yellowish green crystals of nitropeptide 2 were obtained by slow evaporation of methanol solution (ESI

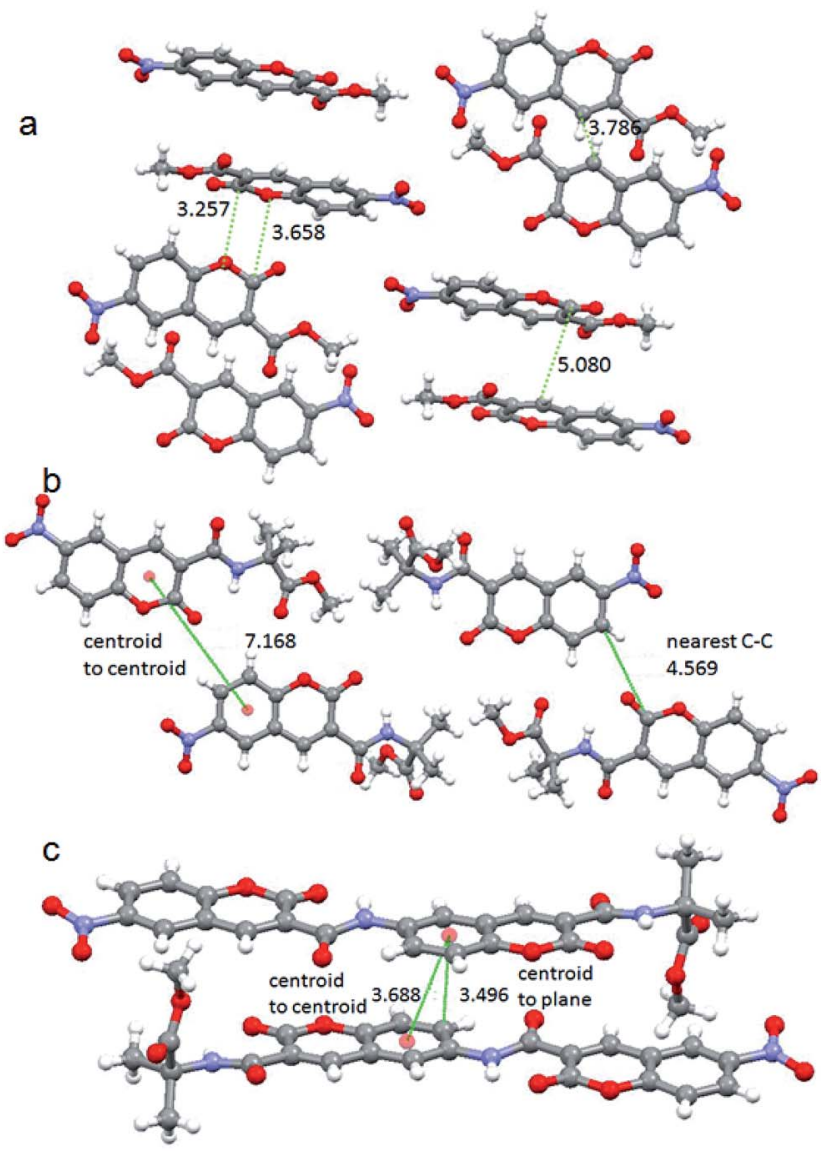

Fig. 7 (a) Solid state packing structure of compound 1 showing $\pi-\pi$ stacking interactions between the coumarin units. (b) Packing diagram of nitropeptide 2 showing parallel arrangement of the molecules. (c) Crystal packing of nitropeptide 3 showing face to face $\pi-\pi$ stacking interaction.

Fig. $4 \dagger$ ). There are two molecules in the asymmetric unit (ESI Fig. $6 \dagger) .{ }^{34}$ There is an intra molecular hydrogen bond between coumarin ring $\mathrm{C}=\mathrm{O}$ and Aib $\mathrm{NH}$ that impose an overall planarity and stability of the molecule. In higher order packing the molecules are in parallel arrangements (Fig. 7b). There is no inter molecular hydrogen bond or $\pi-\pi$ stacking interaction. The centroid to centroid distance is $7.16 \AA$. Though the nitropeptide 2 contains coumarin chromophore, due to non communication between the coumarin units, the compound does not show fluorescence in solid state. The structure of the crystals used for measuring fluorescence is identical with that used for X-ray crystallographic analysis. The triclinic light yellow crystals of nitropeptide 3 were obtained from methanol solution by slow evaporation (ESI Fig. $4 \dagger$ ). There is only one molecule in the asymmetric unit (ESI Fig. $7 \dagger$ ). ${ }^{34}$ There are two intra molecular hydrogen bonds between coumarin(2) ring $\mathrm{C}=\mathrm{O}$ and Aib $\mathrm{NH}$ and coumarin(1) ring $\mathrm{C}=\mathrm{O}$ and coumarin(1) NH. Moreover the $179^{\circ}$ torsion angle between two coumarin units and placement of two lactone units in opposite direction make the molecule almost planer. In higher order packing the nitropeptide $\mathbf{3}$ molecules are in anti parallel arrangements (Fig. 7c) and stabilized by face to face $\pi-\pi$ stacking interactions. The centroid to centroid distance 
Table 1 Backbone torsion angles (deg) of Aib residue for peptide 2 and peptide 3

\begin{tabular}{lrrr}
\hline & \multicolumn{1}{c}{$\omega_{1}$} & \multicolumn{1}{c}{$\psi_{1}$} \\
\hline Peptide 2 & & & \\
Molecule A & -167.56 & -178.50 & -156.83 \\
Molecule B & 172.38 & -51.77 & -44.39 \\
Peptide 3 & -179.78 & 55.02 & 43.83
\end{tabular}

is $3.68 \AA$ and centroid to plane distance is $3.49 \AA$. There is no inter molecular hydrogen bond. Hence, the $\pi-\pi$ interactions between the coumarin units are responsible for the blue emission of nitropeptide 3 in solid state. The crystals used for X-ray analysis is identical with that used for measuring fluorescence. However, on melting and cooling the packing pattern changed, the nitropeptide 3 became amorphous in nature and lost its blue fluorescence. The backbone torsion angles around Aib residue are listed in Table 1. The lauric acid appended 6-amino-coumarin-3carboxylic acid methyl ester shows no crystallinity and change of fluorescence on heating (ESI Fig. $8 \dagger$ ). Hence, Aib is suitable for making fluorescent crystals.

\section{Conclusions}

In conclusion, the packing-induced solid-state emission propensities and thermoresponsive behaviour of peptides containing 6-nitro-coumarin-3-carboxylic acid and $\alpha$-aminoisobutyric acid has been reported. The alkyl chains of Aib affect significantly the solid state molecular packing modes of peptide 2 and modulated the extent of $\pi-\pi$ interactions between the coumarin units. Fluorescence spectroscopy and microscopy confirmed the fluorescence switch of peptide 3 in crystal and in amorphous state. The X-ray crystallography reveals the molecular orientation, packing and the diverse degree of $\pi-\pi$ stacking orbital overlap of adjacent coumarin chromophores of the peptide 3 . The results indicate that apart from the conjugated backbone of the coumarin chromophore, the adjacent alkyl side chain of Aib and linking position have major impact on the solid-state molecular packing as well as the solid-state optical properties. The information obtained here may be helpful to tune the fluorescence probe for biological and diagnostic imaging.

\section{Experimental}

\section{General}

The Aib was purchased from Sigma chemicals. HOBt (1hydroxybenzotriazole) and DCC (dicyclohexylcarbodiimide) were purchased from SRL.

\section{Peptide synthesis}

The peptides were synthesized by conventional solution-phase methods using racemisation free fragment condensation strategy. The C-terminus was protected as a methyl ester. Coupling was mediated by dicyclohexylcarbodiimide/1-hydroxyl benzotriazole (DCC/HOBt). The products were purified by column chromatography using silica (100-200 mesh size) gel as a stationary phase and an $n$-hexane-ethyl acetate mixture as an eluent. The intermediates and final compounds were fully characterized by $500 \mathrm{MHz}$ and $400 \mathrm{MHz}{ }^{1} \mathrm{H}$ NMR spectroscopy, $125 \mathrm{MHz}{ }^{13} \mathrm{C}$ NMR spectroscopy, FTIR spectroscopy and mass spectrometry. The peptides were characterized by X-ray crystallography.

(a) Synthesis of coumarin-3-carboxylic acid methyl ester (4). $2 \mathrm{~mL}(18.6 \mathrm{mmol})$ of salicyldehyde, $2.18 \mathrm{~mL}(19 \mathrm{mmol})$ of dimethyl malanoate and $200 \mu \mathrm{L}$ of piperidine were taken in a 50 $\mathrm{mL}$ round bottom flux and refluxed at $80{ }^{\circ} \mathrm{C}$ for $10 \mathrm{~h}$ with continuous stirring. The reaction mixture was cooled to room temperature. After that ethyl acetate and water was added and shaken vigorously. The ethyl acetate layer was collected and dried over anhydrous $\mathrm{Na}_{2} \mathrm{SO}_{4}$. The products were purified by column chromatography using silica (100-200 mesh size) gel as a stationary phase and an ethyl acetate : $n$-hexane $(1: 3)$ as an eluent. Yield: $3.12 \mathrm{gm}(15.20 \mathrm{mmol}, 88.25 \%)$.

${ }^{1} \mathrm{H}$ NMR ( $\mathrm{CDCl}_{3}, 400 \mathrm{MHz}, \delta$ in ppm): 8.47-8.44 (s, $\left.1 \mathrm{H}, \mathrm{Ar}-\mathrm{H}\right)$, 7.53-7.50 (m, 2H, Ar-H), 7.20-7.24 (m, 2H, Ar-H), $3.81(\mathrm{~s}, 3 \mathrm{H}$, $\left.-\mathrm{OCH}_{3}\right) .{ }^{13} \mathrm{C}$ NMR $\left(100 \mathrm{MHz}\right.$, DMSO- $\left.d_{6}\right)$ 162.66, 158.13, 155.08, 147.99, 143.59, 128.67, 126.13, 119.23, 118.12, 117.78, 52.73. HR-ESI-MS $(\mathrm{m} / \mathrm{z})$ : $[\mathrm{M}+\mathrm{H}]^{+}$calculated for $\mathrm{C}_{11} \mathrm{H}_{9} \mathrm{O}_{4}=204.17$, found 205.19.

(b) Synthesis of 6-nitro coumarin-3-carboxylic acid methyl ester (1). $3.00 \mathrm{~g}$ (15.78 mmol) of compound 4 was dissolved in $7.90 \mathrm{~mL}$ of conc. $\mathrm{H}_{2} \mathrm{SO}_{4}$ and stirred at $0{ }^{\circ} \mathrm{C}$ for $15 \mathrm{~min}$. Then mixture of $3.00 \mathrm{~mL}(55.46 \mathrm{mmol})$ nitric acid and $3.65 \mathrm{~mL}(58.65$ mmol) $\mathrm{H}_{2} \mathrm{SO}_{4}$ was added dropwise and stirred for $1 \mathrm{~h}$ at the temperature range $0-5{ }^{\circ} \mathrm{C}$. Then the reaction mixture was poured into ice-water and filtered. The residue was washed with fresh water repetitively and dried. The product was purified by column chromatography using silica (100-200 mesh) gel and ethyl acetate : hexane $(1: 2)$ as an eluent. Yield: $3.65 \mathrm{gm}$ (14.58 mmol, 92.82\%).

${ }^{1} \mathrm{H}$ NMR ( $\mathrm{CDCl}_{3}, 400 \mathrm{MHz}, \delta$ in ppm): 8.94-8.91 (s, $\left.2 \mathrm{H}, \mathrm{Ar}-\mathrm{H}\right)$, 8.54-8.53 (m, 1H, Ar-H), 7.66-7.64 (m, 1H, Ar-H), 3.86-3.83 (s, $\left.3 \mathrm{H},-\mathrm{OCH}_{3}\right) .{ }^{13} \mathrm{C} \mathrm{NMR}\left(100 \mathrm{MHz}, \mathrm{CDCl}_{3}\right) 162.83,158.10,148.95$, 145.94, 128.62, 126.09, 121.65, 118.19, 117.64, 111.03, 52.31. HR-ESI-MS $(m / z):[\mathrm{M}+\mathrm{H}]^{+}$calculated for $\mathrm{C}_{11} \mathrm{H}_{8} \mathrm{NO}_{6}=249.17$, found 250.18 .

(c) Synthesis of 6-nitro coumarin-3-carboxylic acid (5). To $5.00 \mathrm{~g}(20.06 \mathrm{mmol})$ of compound $1,80 \mathrm{~mL} \mathrm{MeOH}$ and $2(\mathrm{M}) 32$ $\mathrm{mL} \mathrm{NaOH}$ were added and the progress of saponification was monitored by thin layer chromatography (TLC). The reaction mixture was stirred. After $10 \mathrm{~h}$, methanol was removed under vacuum; the residue was dissolved in $150 \mathrm{~mL}$ of water and washed with diethyl ether $(2 \times 70 \mathrm{~mL})$. Then the $\mathrm{pH}$ of the aqueous layer was adjusted to 2 using $1 \mathrm{M} \mathrm{HCl}$ and it was extracted with ethyl acetate $(3 \times 80 \mathrm{~mL})$. The extracts were pooled, dried over anhydrous sodium sulfate, and evaporated under vacuum to obtain compound as a yellowish powder. Yield: $4.38 \mathrm{gm}$ (18.63 mmol, 92.87\%).

${ }^{1} \mathrm{H}$ NMR (DMSO- $d_{6}, 400 \mathrm{MHz}, \delta$ in ppm): 13.90-12.54 (br, $1 \mathrm{H}$, - $\mathrm{COOH}$ ), 8.93-8.78 (m, 2H, Ar-H), 8.50-8.37 (m, 1H, Ar-H), 7.66$7.51(\mathrm{~m}, 1 \mathrm{H}, \mathrm{Ar}-\mathrm{H}) .{ }^{13} \mathrm{C}$ NMR (DMSO- $d_{6}, 125 \mathrm{MHz}, \delta$ in ppm): 
$164.71,158.20,147.60,143.82,128.94,126.53,124.96,120.68$, 118.35, 117.56.

(d) Synthesis of 6-nitro coumarin-Aib-OMe (2). $2.38 \mathrm{~g}$ (10.12 $\mathrm{mmol}$ ) of $\mathrm{O}_{2} \mathrm{~N}-\mathrm{Cum}-\mathrm{OH}$ was dissolved in $20 \mathrm{~mL}$ DCM in an icewater bath. H-Aib-OMe was isolated from $3.06 \mathrm{~g}(20 \mathrm{mmol})$ of the corresponding methyl ester hydrochloride by neutralization and subsequent extraction with ethyl acetate and the ethyl acetate extract was concentrated to $10-12 \mathrm{~mL}$. It was then added to the reaction mixture, followed immediately by $2.09 \mathrm{~g}(10.15$ $\mathrm{mmol})$ dicyclohexylcarbodiimide (DCC) and $1.53 \mathrm{~g}(10.00 \mathrm{mmol})$ of HOBt. The reaction mixture was allowed to come to room temperature and stirred for $48 \mathrm{~h}$. DCM was evaporated and the residue was dissolved in ethyl acetate $(60 \mathrm{~mL})$ and dicyclohexylurea (DCU) was filtered off. The organic layer was washed with $2(\mathrm{M}) \mathrm{HCl}(3 \times 50 \mathrm{~mL})$, brine $(2 \times 50 \mathrm{~mL}), 1 \mathrm{M}$ sodium carbonate $(3 \times 50 \mathrm{~mL})$ and brine $(2 \times 50 \mathrm{~mL})$ and dried over anhydrous sodium sulfate. It was evaporated in a vacuum to yield $\mathrm{O}_{2} \mathrm{~N}-\mathrm{Cum}$ Aib-OMe as a white solid. Yield $2.86 \mathrm{~g}$ (8.56 mmol, 85.62\%).

${ }^{1} \mathrm{H}$ NMR $\left(\mathrm{CDCl}_{3}, 400 \mathrm{MHz}, \delta\right.$ in ppm): 9.08-9.04 (s, 1H, Ar-H), 8.98-8.9 (s, 1H, Ar-H), 8.57-8.46 (m, 1H, Ar-H), 7.62-7.53 (m, $1 \mathrm{H}, \mathrm{Ar}-\mathrm{H}), 7.49-7.46$ (s, 1H, -NH), 3.79-3.71 (s, 3H, -OMe), 1.691.60 (s, 6H, Aib-H).

(e) Synthesis of 6-amino coumarin-Aib-OMe (6). $2.86 \mathrm{gm}$ (8.56 mmol) of compound 2 was taken in a $250 \mathrm{~mL}$ round bottomed flask. The compounds were poured into $150 \mathrm{~mL}$ distilled water. Then $1.43 \mathrm{gm}(25.68 \mathrm{mmol})$ of iron powder and $1.83 \mathrm{gm}$ of $\mathrm{NH}_{4} \mathrm{Cl}(34.24 \mathrm{mmol})$ were added into the solution. Then the mixture was manually stirred for $1.5 \mathrm{~h}$ at heating condition. After the color change of the solution from yellowish to red, the heating and stirring were stopped. Then the reaction mixer was allowed to come down to room temperature and the amine was precipitated out. After that the solutions were filtered by gauche funnel using cilite and the residue was dissolved in mild hot acetone. The solution was dried by rotary evaporator to obtain reddish yellow solid as a pure product. Yield: $2.41 \mathrm{gm}$ (7.92 mmol, 92.52\%).

${ }^{1} \mathrm{H}$ NMR $\left(\mathrm{CDCl}_{3}, 400 \mathrm{MHz}, \delta\right.$ in ppm): 9.32-9.28 (s, $\left.1 \mathrm{H}, \mathrm{Ar}-\mathrm{H}\right)$, 8.76-8.72 (s, 1H, Ar-H), 7.24-7.20 (m, 1H, Ar-H), 7.05-6.97 (m, $1 \mathrm{H}, \mathrm{Ar}-\mathrm{H}), 6.89-6.82(\mathrm{~s}, 1 \mathrm{H},-\mathrm{NH}), 5.33-5.28\left(\mathrm{~s}, 2 \mathrm{H},-\mathrm{NH}_{2}\right), 3.79-$ 3.71 (s, 3H, -OMe), 1.69-1.51 (s, 6H, Aib-H).

(f) Synthesis of 6-nitro coumarin-coumarin-Aib-OMe (3). $1.00 \mathrm{~g}(4.25 \mathrm{mmol})$ of $\mathrm{O}_{2} \mathrm{~N}-\mathrm{Cum}-\mathrm{OH}$ was dissolved in $20 \mathrm{~mL}$ DCM and $1 \mathrm{~mL}$ DMF in an ice-water bath. H-Cum-Aib-OMe was isolated from $1.82 \mathrm{~g}(6.00 \mathrm{mmol})$ of the corresponding methyl ester was added to the reaction mixture, immediately followed by $877 \mathrm{mg}$ (4.25 mmol) dicyclohexylcarbodiimide (DCC) and $612 \mathrm{mg}$ (4.00 mmol) of HOBt. The reaction mixture was allowed to come to room temperature and stirred for $48 \mathrm{~h}$. DCM was evaporated and the residue was dissolved in ethyl acetate (60 $\mathrm{mL}$ ) and dicyclohexylurea (DCU) was filtered off. The organic layer was washed with $2(\mathrm{M}) \mathrm{HCl}(3 \times 50 \mathrm{~mL})$, brine $(2 \times 50 \mathrm{~mL})$, $1 \mathrm{M}$ sodium carbonate $(3 \times 50 \mathrm{~mL})$ and brine $(2 \times 50 \mathrm{~mL})$ and dried over anhydrous sodium sulfate. It was evaporated in a vacuum to yield $\mathrm{O}_{2} \mathrm{~N}$-Cum-Aib-OMe as a white solid. Purification was done by silica gel column (100-200 mesh size) with an ethyl acetate and hexane mixture $1: 4$ as the eluent. Yield: $868 \mathrm{mg}$ (1.66 mmol, 39.05\%).
${ }^{1} \mathrm{H}$ NMR $\left(\mathrm{CDCl}_{3}, 400 \mathrm{MHz}, \delta\right.$ in ppm): 9.38-9.34 (s, 1H, -NH), 9.07-9.01 (s, 1H, Ar-H), 8.89-8.86 (s, 1H, Ar-H), 8.73-8.70 (m, 1H, Ar-H), 8.68-8.59 (m, 1H, Ar-H), 8.27-8.23 (s, 1H, -NH), 8.19$8.10(\mathrm{~m}, 1 \mathrm{H}, \mathrm{Ar}-\mathrm{H}), 7.95-7.84(\mathrm{~m}, 1 \mathrm{H}, \mathrm{Ar}-\mathrm{H}), 7.64-7.62(\mathrm{~m}, 1 \mathrm{H}$, Ar-H), 7.48-7.43 (m, 1H, Ar-H), 3.81-3.72 (s, 3H, - $\mathrm{OCH}_{3}$ ), 3.693.58 (s, 6H, Aib-H). ${ }^{13} \mathrm{C}$ NMR (DMSO-d $6,125 \mathrm{MHz}, \delta$ in ppm): 170.12 , 165.51, 161.10, 161.00, 155.79, 147.01, 145.26, 141.25, $137.24,136.21,132.64,131.49,131.00,126.27,121.01,120.00$, $118.13,116.16,56.41,53.52,26.14$.

\section{NMR experiments}

All NMR studies were carried out on a Brüker AVANCE $500 \mathrm{MHz}$ and Jeol $400 \mathrm{MHz}$ spectrometer at $278 \mathrm{~K}$. Compound concentrations were in the range $1-10 \mathrm{mM}$ in $\mathrm{CDCl}_{3}$ and $\left(\mathrm{CD}_{3}\right)_{2} \mathrm{SO}$.

\section{FTIR spectroscopy}

All reported solid-state FTIR spectra were obtained with a Perkin Elmer Spectrum RX1 spectrophotometer with the KBr disk technique.

\section{Mass spectrometry}

Mass spectra were recorded on a Q-Tof Micro YA263 highresolution (Waters Corporation) mass spectrometer by positivemode electrospray ionization.

\section{Field emission scanning electron microscopy}

Morphologies of the reported peptides were investigated using field emission-scanning electron microscopy (FE-SEM). A small amount of solution of the peptide was placed on a clean silicon wafer and then dried by slow evaporation. The material was then allowed to dry under vacuum at $30{ }^{\circ} \mathrm{C}$ for two days. The materials were gold-coated, and the micrographs were taken in an FE-SEM apparatus (Jeol Scanning Microscope-JSM-6700F).

\section{Single crystal X-ray diffraction study}

Intensity data of peptides were collected with MoK $\alpha$ radiation using Bruker APEX-2 CCD diffractometer. Data were processed using the Bruker SAINT package and the structure solution and refinement procedures were performed using SHELX97. CCDC 1505407, 1505411 and 1505412 contains the crystallographic data for the compound 1, peptide 2 and peptide 3 respectively.

\section{Acknowledgements}

We thank the IISER-Kolkata, India, for financial assistance. A. Pramanik acknowledges the C.S.I.R, India for research fellowship.

\section{Notes and references}

1 (a) X. Wang, O. S. Wolfbeis and R. J. Meier, Chem. Soc. Rev., 2013, 42, 7834-7869; (b) M. D. Allendorf, C. A. Bauer, R. K. Bhakta and R. J. T. Houk, Chem. Soc. Rev., 2009, 38, 1330-1352. 
2 S. Xue, X. Qiu, Q. Sun and W. Yang, J. Mater. Chem. C, 2016, 4, 1568-1578.

3 B. H. Cumpston, S. P. Ananthavel, S. Barlow, D. L. Dyer, J. E. Ehrlich, L. L. Erskine, A. A. Heikal, S. M. Kuebler, I.-Y. S. Lee, D. McCord-Maughon, J. Qin, H. Röckel, M. Rumi, X.-L. Wu, S. R. Marder and J. W. Perry, Nature, 1999, 398, 51-54.

4 (a) L. A. Bagatolli and E. Gratton, Biophys. J., 2000, 78, 290305; (b) M. Ipuy, Y. Y. Liao, E. Jeanneau, P. L. Baldeck, Y. Bretonnie and C. Andraud, J. Mater. Chem. C, 2016, 4, 766-779.

5 R. Petermann, M. Tian, S. Tatsuura and M. Furuki, Dyes Pigm., 2003, 57, 43.

6 J. E. Ehrlich, X. L. Wu, L. Y. Lee, Z. Y. Hu, H. Rockel, S. R. Marder and J. W. Perry, Opt. Lett., 1997, 22, 1843.

7 J. Chan, S. C. Dodani and C. J. Chang, Nat. Chem., 2012, 4, 973-984.

8 X. Zhang, Z. Chi, B. Xu, L. Jiang, X. Zhou, Y. Zhang, S. Liu and J. Xu, Chem. Commun., 2012, 48, 10895-10897.

9 S. Yamaguchi, I. Yoshikawa, T. Mutai and K. Araki, J. Mater. Chem., 2012, 22, 20065-20070.

10 T. Sarma, P. K. Panda and J. Setsune, Chem. Commun., 2013, 49, 9806-9808.

11 Y. Dong, B. Xu, J. Zhang, X. Tan, L. Wang, J. Chen, H. Lv, S. Wen, B. Li, L. Ye, B. Zou and W. Tian, Angew. Chem., Int. Ed., 2012, 51, 10782-10785.

12 L. Wang, K. Wang, B. Zou, K. Ye, H. Zhang and Y. Wang, Adv. Mater., 2015, 27, 2918-2922.

13 M. Teng, X. Jia, S. Yang, X. Chen and Y. Wei, Adv. Mater., 2012, 24, 1255-1261.

14 R. Misra, T. Jadhav, B. Dhokale and S. M. Mobin, Chem. Commun., 2014, 50, 9076-9078.

15 T. Liu, A. D. Chien, J. Lu, G. Zhang and C. L. Fraser, J. Mater. Chem., 2011, 21, 8401-8408.

16 T. Han, Y. Zhang, X. Feng, Z. Lin, B. Tong, J. Shi, J. Zhi and Y. Dong, Chem. Commun., 2013, 49, 7049-7051.

17 D. Yan, A. Delori, G. O. Lloyd, T. Friscic, G. M. Day, W. Jones, J. Lu, M. Wei, D. G. Evans and X. Duan, Angew. Chem., Int. Ed., 2011, 50, 12483-12486.

18 Q. Feng, M. Wang, B. Dong, J. He and C. Xu, Cryst. Growth Des., 2013, 13, 4418-4427.

19 T. Bullard, K. L. Wustholz, E. D. Bott, M. Robertson, P. J. Reid and B. Kahr, Cryst. Growth Des., 2009, 9, 982-990.

20 T. Zhou, T. Jia, S. Zhao, J. Guo, H. Zhang and Y. Wang, Cryst. Growth Des., 2012, 12, 179-184.

21 M. Li, Q. Zhang, J.-R. Wanga and X. Mei, Chem. Commun., 2016, 52, 11288-11291.

22 Y. Fan, Y. Zhao, L. Ye, B. Li, G. Yang and Y. Wang, Cryst. Growth Des., 2009, 9, 1421-1430.
23 S. K. Rajagopal, A. M. Philip, K. Nagarajan and M. Hariharan, Chem. Commun., 2014, 50, 8644-8647.

24 G. Zhang, J. Lu, M. Sabat and C. L. Fraser, J. Am. Chem. Soc., 2010, 132, 2160-2162.

25 S. C. Rasmussen, S. J. Evenson and C. B. McCausland, Chem. Commun., 2015, 51, 4528-4543.

26 G. Liang, F. Ren, H. Gao, Q. Wu, F. Zhua and B. Z. Tang, Polym. Chem., 2016, 7, 5181-5187.

27 (a) R. J. Nedumpara, K. J. Thomas, V. K. Jayasree, C. P. Girijavallabhan, V. P. N. Nampoori and P. Radhakrishnan, Appl. Opt., 2007, 46, 1159-1168; (b) K. Hara, Z. S. Wang, T. Sato, A. Furube, R. Katoh, H. Sugihara, Y. Danoh, C. Kasada, A. Shinpo and S. Suga, J. Phys. Chem. B, 2005, 109, 15476-15482.

28 M. Ikeda, R. Ochiaand and I. Hamachi, Lab Chip, 2010, 10, 3325-3334.

29 S. A. Slavoff, D. S. Liu, J. D. Cohen and A. Y. Ting, J. Am. Chem. Soc., 2011, 133, 19769-19776.

30 (a) V. Moretto, M. Crisma, G. M. Bonora, C. Toniolo, H. Balaram and P. Balaram, Macromolecules, 1989, 22, 2939-2944; (b) P. I. Haris and D. Chapman, Biopolymers, 1995, 37, 251-263.

31 B. T. Makowski, B. Valle, K. D. Singer and C. Weder, J. Mater. Chem., 2012, 22, 2848-2850.

32 A. Adawy, W. J. P. van Enckevort, E. S. Pierson, W. J. de Grip and E. Vlieg, CrystEngComm, 2014, 16, 9800-9809.

33 J. Ahn, S. Park, J. H. Lee, S. H. Jung, S.-J. Moon and J. H. Jung, Chem. Commun., 2013, 49, 2109-2111.

34 Single-crystal X-ray analysis of peptides 1 and 2 were recorded on a Bruker high resolution X-ray diffractometer instrument. The structures were solved by a direct method and refined by least-squares calculations on $F^{2}$ for all independent reflections (SHELXL-2013). ${ }^{35}$ Crystal data of compound 1: $\mathrm{C}_{11} \mathrm{H}_{7} \mathrm{~N}_{1} \mathrm{O}_{6}, M_{\mathrm{w}}=249.18, I 2 / a, a=20.178(2)$ $\AA$ 局 $b=4.0966(4) \AA, c=25.538(2) \AA, \alpha=90^{\circ}, \beta=99.66(9)^{\circ}$, $\gamma=90^{\circ}, V=2081.1(3) \AA^{3}, Z=8, \mathrm{dm}=1.591 \mathrm{Mg} \mathrm{m}^{-3}, K=$ 293, $R_{1}=0.0641$ and $\mathrm{w} R_{2}=0.1721$ for 2014 data with $I>$ $2 \sigma(I)$. Crystal data of nitropeptide 2: $\mathrm{C}_{15} \mathrm{H}_{14} \mathrm{~N}_{2} \mathrm{O}_{7}, M_{\mathrm{w}}=$ 334.28, $P \overline{1}, a=7.8470(3) \AA, \quad b=14.2490(8) \AA, c=$ $15.0925(8) \AA, V=1488.03(15) \AA^{3}, Z=4, \mathrm{dm}=1.492 \mathrm{Mg}$ $\mathrm{m}^{-3}, K=153, R_{1}=0.0373$ and $\mathrm{w} R_{2}=0.0967$ for 5228 data with $I>2 \sigma(I)$. Crystal data of nitropeptide 3: $\mathrm{C}_{25} \mathrm{H}_{19} \mathrm{~N}_{3} \mathrm{O}_{10}$, $M_{\mathrm{w}}=521.43, P \overline{1}, a=7.8580(8) \AA, b=11.5608(12) \AA, c=$ $13.8689(11) \AA, V=1188.1(2) \AA^{3}, Z=2, \mathrm{dm}=1.458 \mathrm{Mg}$ $\mathrm{m}^{-3}, K=293, R_{1}=0.0726$ and $\mathrm{w} R_{2}=0.1887$ for 4050 data with $I>2 \sigma(I)$. CCDC 1505407, 1505411 and 1505412 contains the crystallographic data for the crystals respectively.

35 G. M. Sheldrick, Acta Crystallogr., Sect. C: Struct. Chem., 2015, 71, 3-8. 